\title{
Validity and Reliability of Green Skills Instrument
}

\author{
Arasinah Kamis ${ }^{\mathrm{a}}$, Mohd Azlan Mohammad Hussain ${ }^{a}$, Che Ghani Che Koba, Faizal Amin Nur Yunus ${ }^{\mathrm{b}}$, Mohd Bekri Rahim ${ }^{\mathrm{b}}$ \\ ${ }^{a}$ Faculty Technical and Vocational, Universiti Pendidikan Sultan Idris, 35900 Tanjung Malim, Perak, Malaysia \\ ${ }^{b}$ Faculty of Technical and Vocational Education, Tun Hussein Onn University, 86400 Batu Pahat, Johor, Malaysia
}

*Corresponding author: arasinah@ftv.upsi.edu.my

Article history: Received: 17 September 2017 Received in revised form: 24 March 2018 Accepted: 6 Jun 2018 Published online: 22 November 2018

\begin{abstract}
Green Skills (GS) are the skills based on strong sustainability development from the aspects of technical, value knowledge and attitude that are needed by the workforce in developing economy and environment in the business, industry and society. The objective of this research was to validate the GS instrument. This research adopted the survey research method. Cluster random sampling and simple random sampling methods were utilised in selecting a total of 446 Secondary school students who enrolled the subject of Design all over Peninsular Malaysia. Structural Equation Modelling (SEM) analyses were used to determine validity and reliability in measurement model. Measurement model was fitted the data and was accepted base on suitability index (fit indices), that has been achieved namely CMIN $\chi^{2}=595.204$, with degrees of freedom (df) 132 , CMIN/df=4.509 $(\leq 5.0)$, incremental fit CFI \& IFI $(\leq 0.9)$, and absolute fit RMSEA $=0.8(\leq 0.8)$. The instrument has been proven to be a good instrument and passed the psychometrics standards. The research findings showed there were a total of 10 elements must be present in the students. The research implicated that GS Model can be used as guidance in cultivating GS in the learning process. This GS Model is expected to cultivate a balanced environment from the aspects of attitude, knowledge and values that are needed in the students. This GS Model also can be used as the basis in developing curriculum as an added-value in training design. Furthermore, it can be used as a module in learning process that gives importance to environmental awareness among students
\end{abstract}

Keywords: Green skills; sustainability development; environmental awareness; green practice; attitude; knowledge

\begin{abstract}
Abstrak
Kemahiran Hijau adalah kemahiran yang berlandaskan kepada kelestarian pembangunan yang mampan dari segi teknikal, pengetahuan nilai dan sikap yang diperlukan oleh tenaga kerja untuk membangunkan ekonomi dan alam sekitar yang mampan dalam perniagaan, industri dan masyarakat. Objektif kajian adalah untuk mengesahkan instrumen GS. Rekabentuk kajian ini menggunakan pendekatan kuantitatif melalui kajian tinjauan. teknik persampelan rawak berkelompok dan rawak mudah telah digunakan untuk memilih seramai 446 orang pelajar tingkatan empat yang mengambil mata pelajaran Reka Cipta di seluruh Semenanjung Malaysia. Analisis Structural Equation Modeling (SEM) digunakan untuk menentukan kesahan dan kebolehpercayaan dalam model pengukuran (measurement model). Model pengukuran adalah sesuai dengan data dan diterima berdasarkan indeks kesesuaian, iaitu CMIN $\chi^{2}=595.204$, dengan darjah kebebasan (df) 132, CMIN/df=4.509 $(\leq 5.0)$, incremental fit CFI \& IFI $(\leq 0.9)$, dan absolute fit RMSEA=0.8( $\leq 0.8)$. Instrumen ini terbukti adalah instrumen yang baik dan memenuhi kriteria standard psikometrik. Dapatan kajian mendapati terdapat sepuluh elemen GS yang perlu ada dalam diri pelajar. Implikasi kajian menunjukkan bahawa Model GS boleh dijadikan sebagai rujukan untuk menerapkan GS dalam proses pembelajaran. Model GS ini dijangkakan akan dapat memupuk keseimbangan alam sekitar dari segi sikap, pengetahuan dan nilai yang perlu ada di dalam diri seorang pelajar. Model GS ini juga boleh dijadikan asas dalam pengubalan kurikulum sebagai nilai tambah dalam reka bentuk latihan. Seterusnya boleh dijadikan sebagai satu modul dalam proses pengajaran yang menitkberatkan kepada kesedaran alam sekitar dalam kalangan pelajar.
\end{abstract}

Kata kunci: Kemahiran hijau; pembangunan mampan; kesedaran persekitaran, amalan hijau, sikap, pengetahuan

(C) 2018 Penerbit UTM Press. All rights reserved

\subsection{INTRODUCTION}

Green Skills is related to the green technologies which are the importance in nurturing the environment, environmental awareness, attitude and readiness to learn regarding environmental sustainability (Pavlova, 2012). Green Skills is a concept that emphasizes the environmental elements in daily life and how individuals will ensure the environmental sustainability in the aspects of economy, community and country (Arasinah, Ramlee, Waliza, \& Bushra, 2016). CEDEFOP (2012a ), MacDiarmid (2015), also defined Green Skills as knowledge, ability, values and attitudes needed to live in developing and supporting the strong community formation and efficient resources management. On the other hand, Strietska-llina, Hofman, Haro and Jeon (2011); McDonald's, Condon and Riordan, (2012); Council of Australian Governments, (COAG) stated that Green Skills refers to a type of skill based on strong sustainability development from the aspects of technical, value knowledge and attitude that are needed by the workforce in developing economy and environment in the business, industry and society. Green Skills can also be deemed as knowledge and skills needed to live and work in a responsible manner 
towards the environment, and to manage the effects climate changes. The green concept is more towards the term of go green that is being applied all around the world in order to nurture the environment such as the concept of recycling (3R), no-plastic day and solid waste separation.

\subsection{LITERATURE REVIEW}

\section{Green Skills}

Environment related education had long been introduced in school syllabus in Science subject in general. Furthermore, the teachers are encouraged to bring up the element of environment across the curriculum. However, the fact remains, although environment related education have been carried out throughout the curriculum for a long period of time, the level of environmental awareness is still low (Jamilah \& Hasrina, 2011; Shahrom, Noor Ezlin, Fatihah, Othman, \& Hassan, 2015; Arasinah, Ramlee, Waliza, \& Bushra, 2016). Mukoni (2013) found that environmental education knowledge received through school curriculum does not bring any changes among community, students and teachers. Thus, the role of Technical Vocational Education and Training (TVET) in delivering the Green Skills is desperately sought after in cultivating love towards the environment (Diep \& Hartmann, 2016; Arasinah, Amarumi, Bushra Limuna, Normah, \& Faizal, 2017a). As concluded by Meenakshi and Leela (2014), education has the power to place the responsibility of developing future environmental sustainability education without having to focus on new policies. Green Skills is a concept that needs to be inserted into the school curriculum with the specific aim of creating awareness among the community regarding the importance of environmental sustainability through education (Ramlee, 2015; Arasinah et al., 2017b). TVET is needed to play its roles in giving Green Skills parallel to the Green Technologies because the industry workers that are involved in economic development are from such fields as tourism, energy resources and product recycling (UNEVOC, 20142. These skills must be inculcated in the technical education because this process could render effects and enrich the skills of workforce resources (Pavlova, 2012; Bushro Limuna, Arasinah, Che Ghani, Kiong, \& Md. Bekri, 2016).

Thus, Green Skills is an aspect that needs to be added in TVET curriculum sustainability in order to produce competent students and also need to be applied in school curriculums (Suhaimi, Mahmud, Muhamad Ariff, Hamzah dan Saud, 2010; Pavlova \& Huang, 2013; Arasinah et al., 2016). Therefore, the curriculum should prepare a holistic approach where the students grow by appreciating and nurturing their environment (Error! Reference source not found.. Taylor, Quinn dan Eames (2015) also suggested the need for a different approach due to the fact that although environmental education have long been taught at schools, it still unable to form proper behaviour towards the environment CEDEFOP (2010 b) listed a number of Green Skills aspects that can be implemented at schools to refresh values towards normalising green technologies and also to produce community that has Green Skills that can drive the economy towards strong development and has 50\% of skilled workforce by 2020 (Siti Nor Syazwani et al., 2012; Arasinah et al., 2017 ). Due to that, Green Skills model will be broadened to develop attitude, knowledge and values among students in order to ensure that whatever action or deeds are aimed at ensuring the development of the nation. With this, indirectly, the current young generation can be cultivated with the awareness, develop positive habits related to importance of environmental sustainability and preventing continuous environmental pollution.

\section{Attitude, Value and Knowledge}

Kennedy and Chow (2013) stated that schools play a role in increasing understanding of environmental values among the community which influences not only the attitude but also the behaviour of individuals. Research regarding the attitude towards the environment by Mukesh, Preetam, and Masnsi (2015), Narendra and Karnika (2013), Tan and Lau (2010), Mustafa (2010), Ernesto (2004), Nor Kalsum (2016), Che Ku Norhaniza (2014), Jamilah, Hasrina, Hamidah and Juliana (2011) showed that there is a positive relationship between attitude and environment, where individuals have the desire to protect the environment from pollutions. This attitude can dominate the individuals towards the desire for a healthy environment by involving in pro-environment acts such as recycling papers at schools and homes, and reduce usage of tissues and plastics. Environmental awareness also showed the elements of attitude after environment-related activities (Rohana et al., 2013; Mohd Ali, Abdul Hadi, Norfarah, Noor Hasyimah \& Corrienna, 2014). From the affective aspect, Erdogan (2015) and Rose Amnah (2015). Erdogan (2015), stated that the attitude towards the environment can be cultivated through programs related to environments such as Summer Environmental Education Program (SEEP). Research report (UNICEF, 2011) proved that students showed positive attitude toward nurturing and sustaining the environments where its able to reduce global warming effects.

Values development in individuals is very crucial. This depended on the acceptance during learning process. The aspect of teaching experience is also an aspect that is often studied in education practices researches. As mentioned in Mead (2003), teachers are unable to cultivate values due to lack of experience in implementation. Among the few findings in specific subjects such as Noorlela Ahmad (2008), it was found that the teachers faced difficulties in implementing values cultivation in the subject of Principles of Accounts. Habsah Ismail (2000), I her research found that the social sciences teachers showed higher understanding compared to pure sciences teachers regarding the aspects of knowledge, skills, and values in Integrated Secondary School Curriculum (ISSC). These findings showed that certain subjects face difficulties in implementing values cultivation. The lack of emphasize on values by subjects' teachers could lead to students being unable to relate certain knowledge with values development. Hanifah (2014) concluded that pupils do not have the ability yet to act positively toward the environment and yet to be able to change the students to practice environmental sustainability education. Furthermore, Saravanan, Rosta, and Ahmad (2013) found that the level of students' sustainability practices is at moderate level. This was related to the lack of sustainability practices in their daily life where the students have yet to achieve sustainability usage practices in order to reduce environmental problems.

Tiwi Kamidin and Samsilah (2014) concluded that there are many individuals who have the knowledge regarding environmental awareness; however they still engage in practices that destroy the environment. This happened to the extent where the existence of environmental issues were suggested to be included as part of the environmental education. Environmental Education went through changes from time to time but only for a certain period of time and then it was not implemented. A research carried out regarding sustainability development under the Sustainable School-Environmental Award (Sekolah Lestari Anugerah Alam Sekitar) program by 
Hanifah, (2014) found that the level of students' knowledge regarding environmental sustainability education was still moderate. The involvement of the students in SLAAS program was seen as a positive start in spreading knowledge regarding sustainability education (Education for Sustainable development, ESD). Knowledge related to solid waste management is also a major issue faced by many townships in developing nations. Research by Hasnah, Dody, Noraziah, Maznah and Sarifah, (2010), found 47.9\% respondents does not have the knowledge on methods to reduce domestic solid waste and only $29.1 \%$ respondents practice recycling at home. This indicated that the level of community's knowledge and awareness of solid waste separation was still unsatisfactory. The findings suggested that consumers reuse the used items by repairing it, because it can still benefit the community by selling it and this can reduce waste and protect the environment. Knowledge regarding Green Technologies is also related to level of solid waste management among students. Licy et al. (2013) stated that the level of awareness among students toward the waste management issues in Higher Education Institutions was higher compared to $44 \%$ of secondary school students. This could be due to the fact that students at Higher Education Institutions have more awareness regarding solid wate management practices. This research also suggested that knowledge related to solid waste management should be given starting from primary schools so that students are more aware of their responsibility in caring for the environment.

\section{Objectives}

The objectives of this research are:

(1) To assess the reliability of the developed instrument.

(2) To test construct validity of the instrument.

\subsection{ENVIRONMENTAL EDUCATION MODEL}

Model of Palmer and Neal (1998), Sterling and Cooper (1992), Model Hungerford and Vokl (1998), Giolitto, Mathot, Pardo and Vergnes (1997) and Model of KAP adapted from Ramsey and Rickson (1976). All the environmental education models emphasise holistic individual development through awareness, understanding, knowledge, skills, attitude, value and actions. The education process starts with emphasising awareness, knowledge and understanding, skills, attitude, values, ethics and actions towards sustainable environment. Figure 1 showed the theoretical framework that combined all the environmental education models to form the core of this research.

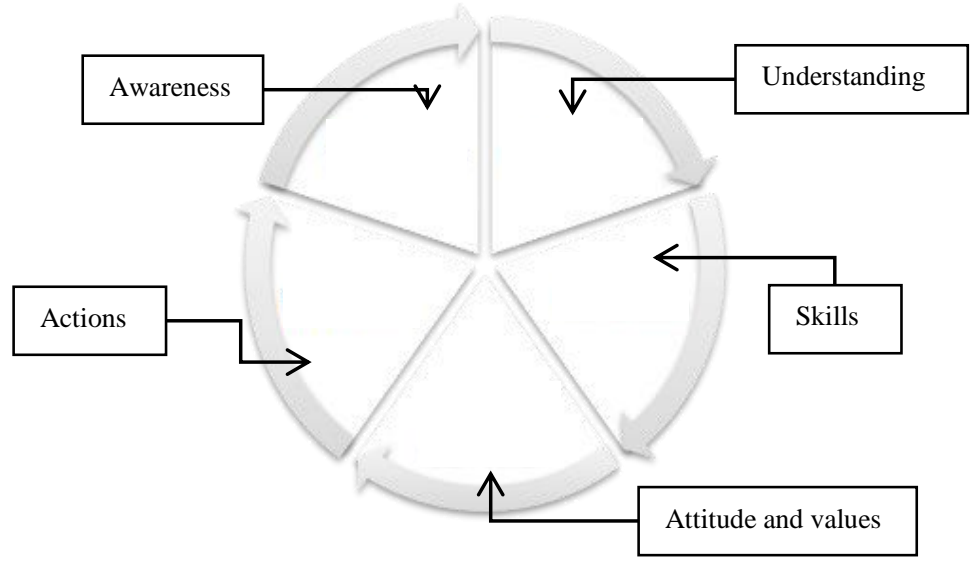

Figure 1 Theoritical framework

\subsection{METHODOLOGY}

This research utilised the quantitative design by applying the surveying research method. The research population consisted of 5181 students that took Design subject at 231 schools in Peninsular Malaysia. Two levels of random sampling method was used which were the combination of cluster random sampling and simple random sampling (Creswell, 2013 \& Babbie, 2001). The number of samples needed for this research was determined using the calculation suggested by Bartlett, Kotrlik dan Hinggins (2001) that uses the formula of Cochran (1977). Based on the calculation, the needed sample size was 446 students.

\section{Instruments}

The research instruments consisted of four constructs which are attitude, values, knowledge and green skills. The attitude instrument was adapted from Children's Environmental Attitude and Knowledge Scale (CHEAKS) by Frank, Leeming, William O'Dwyer, and Bruce Bracken (1995). The researchers used this instrument because the items measure the individual's attitude towards environment. This instrument uses 5 (five) likert scales. As for the knowledge construct, Environmental Attitudes and Knowledge of Teenage Consumer by Othman, Ong, \& Lim (2004) was used. This instrument also uses 5 (five) likert scales. As for the values construct, five elements were used which were i) Allah SWT / God; ii) relationship with teachers; iii) relationship with friends; iv) relationship with self; and v) relationship with environment. The Green Skills Instrument consisted of 10 constructs that also uses 5 (five) likert scales. The items were developed based on the findings of interviews, document analyses and literature reviews and with the consent of the experts. 
Validity and Reliability of Instrument

Table 1 shows the findings of pilot test which are the instrument's reliability value. Alpha Cronbach values showed that the used instrument is good and effective with high level of consistency which renders it fit for real research.

Table 1 Result of instrument's reliability

\begin{tabular}{clc}
\hline & Item & $\begin{array}{c}\text { Alpha Cronbach Value } \\
\text { (Pilot Test) }\end{array}$ \\
\hline Attitude & & 0.746 \\
a) & Oral commitment & 0.761 \\
b) & Real commitment & 0.760
\end{tabular}

\begin{tabular}{lll}
\hline Knowledge & 0.768 \\
\hline Value & Relationship with god & 0.754 \\
a) & Relationship with teachers & 0.740 \\
b) & Relationship with friends & 0.768 \\
c) & Relationship with self & 0.741 \\
d) & Relationship with environment & 0.766 \\
e) &
\end{tabular}

\begin{tabular}{clr}
\hline Green Skills Elements & 0.743 \\
a) & Communication & 0.743 \\
b) & Intellectual & 0.750 \\
c) & Self Develop & 0.744 \\
d) & Learning & 0.751 \\
e) & Career & 0.734 \\
f) & Environment awarness & 0.756 \\
g) & Green Practice & 0.764 \\
h) & STEM & 0.752 \\
i) & Entreprenurship & 0.756
\end{tabular}

Data Analysis

The data were analysed based on structural equation modelling analysis (SEM) using the AMOS software (version 21). The research questionnaire consisted of 82 items (4 constructs). Basically, SEM is a procedure that combines some of the best multivariate analysis to test the validity of theoretical constructs and the relationships between a set of concepts that are represented by different measurement variables (Hair, Black, Babin, Anderson, \& Tatham, 2010). The researcher simply used the measurement model to verify the validity of the construct of the instrument. The initial stage of the measurement model should conduct confirmatory factor analysis (CFA). The researcher conducted examinations of convergent validity and discriminant validity. Good convergent validity is determined by looking at the weighting factor $(\geq .5$ or better $>.7$ ) (Hair et al., 2010), Average Variance Extracted (AVE) (> .5) (Fornell \& Larcker, 1981) and construct reliability $>.70$ indicates the internal consistency is good. Meanwhile, discriminant validity is determined by comparing the AVE for two factors with $\mathrm{r}^{2}$ (squared of the correlation between the two factors), which is valid if the specified AVE > $\mathrm{r}^{2}$ (Fornell \& Larcker, 1981; Hair, et al., 2010). CFA was also used to check the functionality of the measurement and analysis model depends on the compatibility index (goodness of fit). Hair et al., (2010) stated that the index of the correspondence consists of three types of fits; incremental fit (TLI, CFI, GFI), absolute fit (RMSEA), and parsimonious fit (CMIN/df). At least three or four congruity index of absolute fit and incremental fit is adequate (Hair et al., 2010).

\subsection{RESULTS AND DISCUSSION}

The analysis used Structural Equation Modelling (SEM) analysis to confirm that the findings are accurate and consistent. A total of 82 items was measured for validity and reliability of each subconstruct. Confirmatory factor analysis (CFA) was used to measure the items' construct validity in each sub construct that measure Green Skills Instrument. The first step in this measurement model is to determine the convergent validity and discriminant validity. Table 2 shows the result of CFA for measurement model, the factor loading of more than 0.70, Average variance extracted (AVE) more than 0.50 and Composite reliability (CR) more than 0.70, thus this Green Skills instrument has good convergent validity and adequate reliability. 
Table 2 Result of CFA for measurement model

\begin{tabular}{|c|c|c|c|c|c|}
\hline \multirow[b]{2}{*}{ Construct } & \multirow[b]{2}{*}{ Item } & \multirow[b]{2}{*}{$\begin{array}{c}\text { Internal reliability } \\
\text { Cronbach alpha }\end{array}$} & \multicolumn{3}{|c|}{ Convergent validity } \\
\hline & & & $\begin{array}{c}\text { Factor loading } \\
(>0.5)\end{array}$ & $\begin{array}{c}\text { Composite } \\
\text { reliability }^{1}(>0.7)\end{array}$ & $\begin{array}{l}\text { Average variance } \\
\text { extracted }^{2}(>0.5)\end{array}$ \\
\hline \multirow{7}{*}{$\begin{array}{l}\text { Attitude } \\
(7 \text { items })\end{array}$} & ks1 & 0.835 & 0.948 & 0.965 & 0.799 \\
\hline & ks2 & & 0.881 & & \\
\hline & ks3 & & 0.804 & & \\
\hline & ks6 & & 0.835 & & \\
\hline & ks7 & & 0.940 & & \\
\hline & ks8 & & 0.990 & & \\
\hline & ks9 & & 0.844 & & \\
\hline \multirow{6}{*}{$\begin{array}{l}\text { Value : } \\
(5 \text { items }) \\
(4 \text { items }) \\
(5 \text { items }) \\
(4 \text { items }) \\
(5 \text { items) }\end{array}$} & & 0.894 & 0.644 & 0.902 & 0.647 \\
\hline & Nature & & 0.788 & & \\
\hline & Self & & 0.789 & & \\
\hline & Peer & & 0.853 & & \\
\hline & Teacher & & 0.812 & & \\
\hline & God & & 0.782 & & \\
\hline \multirow{3}{*}{$\begin{array}{l}\text { Green Skills: } \\
\text { (7 items) } \\
(4 \text { items })\end{array}$} & & 0.927 & 0.862 & 0.934 & 0.587 \\
\hline & Communication & & 0.759 & & \\
\hline & Interpersonal & & 0.745 & & \\
\hline (4 items) & Intellectual & & 0.832 & & \\
\hline (5 items) & Self Develop & & 0.839 & & \\
\hline (6 items) & Learning & & 0.804 & & \\
\hline (3 items) & Career & & 0.753 & & \\
\hline (5 items) & Environment & & 0.731 & & \\
\hline \multirow{3}{*}{$\begin{array}{l}(6 \text { items) } \\
(5 \text { items) } \\
(4 \text { items) }\end{array}$} & Green Practice & & 0.745 & & \\
\hline & STEM & & 0.769 & & \\
\hline & Entrepreneurship & & 0.674 & & \\
\hline \multirow{3}{*}{$\begin{array}{l}\text { Knowledge } \\
\text { (3 items) }\end{array}$} & p1 & 0.921 & 0.791 & 0.760 & 0.522 \\
\hline & p2 & & 0.815 & & \\
\hline & $\mathrm{p} 4$ & & 0.527 & & \\
\hline
\end{tabular}

Note:

${ }^{1}$ Composite reliability $=\{($ square of the summation of the factor loadings $) /($ square of the summation of the factor loadings $)+($ square of the summation of the error variances)\}

${ }^{2}$ Composite reliability $=\{($ summation of the square of the factor loadings $) /\{($ summation of the square of the factor loadings $)+($ summation of the error variances $)\}$

\section{Discriminant Validity of Constructs}

Table 2 shows the discriminant valivity of constructs and to check the suitability ( fit) of the measurement model, the analysis depended on the fitness index. At least 3 or 4 fitness index criteria should be fulfilled. Green Skills instrument consisted of 4 sub constructs with 82 items namely (i) Attitude, (ii) Value, (iii) Green Skills, and (iv) Knowledge. According to Fornell and Larcker (1981), discriminant validity is determined by comparing the AVE value for two factors with $\mathrm{r}^{2}$ (square of correlation between two factors). Discriminant validity is confirmed if AVE $>r^{2}$. Table 3 shows that the value of AVE is greater than $r^{2}$ for all the skills subconstructs. This showed that the Green Skills instrument has good discriminant validity (good internal consistency).

Table 3 Discriminant validity of constructs

\begin{tabular}{lcccc}
\hline Constructs & $\mathbf{A}$ & $\mathbf{V}$ & $\mathbf{G S}$ & $\mathbf{K}$ \\
\hline (1) Attitude (A) & $\mathbf{0 . 6 3 3}$ & & \\
(2) Value (V) & 0.240 & $\mathbf{0 . 6 4 2}$ & \\
(3) Green Skills (GS) & 0.270 & 0.336 & $\mathbf{0 . 7 5 7}$ & \\
(4) Knowledge (K) & 0.168 & 0.348 & 0.203 & $\mathbf{0 . 5 8 3}$ \\
& & & \\
\hline
\end{tabular}

\section{Criteria for Fit Index}

Figure 2 shows the results of the five-factor measurement model of Green Skills elements. All fit indices exceeded the recommended threshold values CFI, IFI $>0.90$, RMSEA $<0.089$ and these values are acceptable (Table 3 ). The chi-square goodness-of-fit value obtained was 595.204. Consequently, the revised model is considered as having passed all the criterion values and indicate that the model fit the data.The inter-factor correlations were $r=0.53,0.40,0.57,0.45$ and 1.0, substantiated the hypothesis that the six factors were distinct. The loadings range was between 0.53 and 1.0. Succinctly, construct validity for skills competencies are supported. The result above was achieved after taking into consideration the Modification Index (MI). As a final result, only 82 items fit the model and fulfil the psychometric standard. 
Table 4 Criteria for fit index

\begin{tabular}{|c|c|c|c|}
\hline Index & Author & Suggested Value & Measurement \\
\hline CMIN & Tabachnik \& Fidell (2013) & $\begin{array}{l}\text { Report if number of samples are } \\
\text { more than } 100-200\end{array}$ & 992.119 \\
\hline $\begin{array}{l}\text { CMIN/DF (Degrees of } \\
\text { freedom) }\end{array}$ & $\begin{array}{l}\text { Marsh \& Hocevar(1985) } \\
\text { Bentler (1990) }\end{array}$ & $\begin{array}{c}<5.0 \\
<5.0 \\
\text { Report if the number of samples }> \\
200\end{array}$ & 2.084 \\
\hline $\begin{array}{l}\text { CFI (Comparative of Fit } \\
\text { Index }\end{array}$ & $\begin{array}{l}\text { Bentler (1990) } \\
\text { Hatcher (1994) } \\
\text { Schumarker \& Lomax (2010) }\end{array}$ & $\begin{array}{l}>.90 \\
>.90 \\
>.90\end{array}$ & 0.947 \\
\hline TLI (Tucker-Lewis Index & Bentler \& Bonett (1980) & $>.90$ & 0.941 \\
\hline $\begin{array}{l}\text { RMSEA (the root mean } \\
\text { square error of } \\
\text { approximation) }\end{array}$ & $\begin{array}{l}\text { Byrne (2010) } \\
\text { Hu \& Bentler (1999) }\end{array}$ & $\begin{array}{l}>.08 \\
>.05\end{array}$ & 0.057 \\
\hline
\end{tabular}

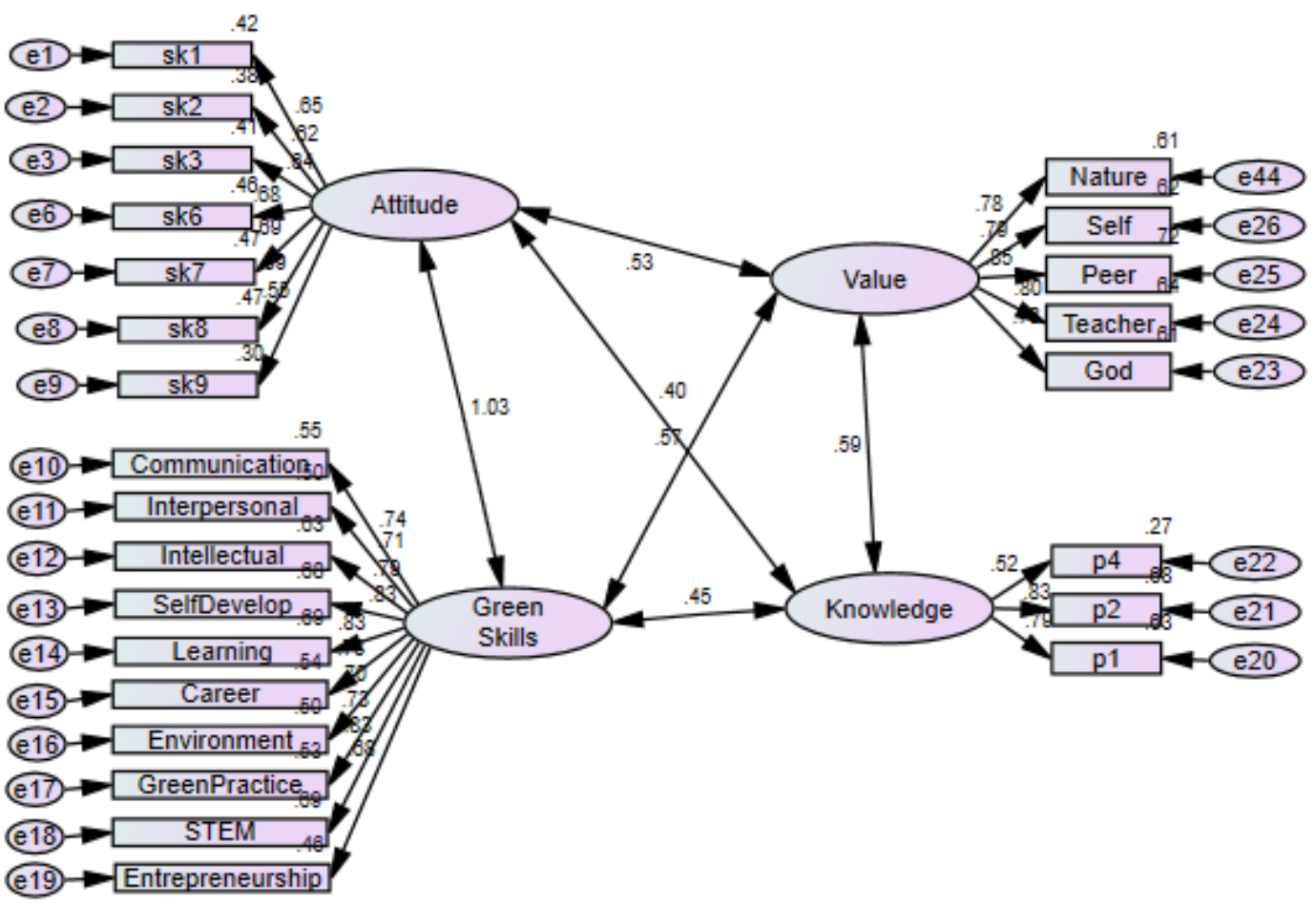

Chi-Square $=595.204$

$\mathrm{DF}=132$

Relative Chi-Sq $(<5.0)=4.509$

$\mathrm{p}=.000$

$\operatorname{GFI}(>=.9)=\lg f i$

AGFI $(>=, 9)=$ lagii

$\mathrm{CFI}(>=.9)=.909$

IFI $(>=.9)=.909$

$\mathrm{NFI}(>=9)=.887$

$\operatorname{TLI}(>=.9)=.895$

RMSEA $(<=.08)=.089$

AIC (lower better) $=709.204$

(Standardized estimates)

Figure 2 Measurement model of green skills 
Based on the testing in reflective measurement model analyses, validity and reliability of the constructs could be done. Although this research is of explorative nature, the findings showed CR and Cronbach alpha values that are satisfactory. This clearly shows that the constructs are consistent and stable for that particular measurement model. Thus, each construct is reliable and suitable for the measurement model. This supports the findings of Hair et al. (2014) that clarified reliability as the main requirement for validity measurement. Adhering to all the rules of testing, a total of 64 items were eliminated in order to ensure the remaining items have good validity levels. Conclusively, after all the testing was completed for this reflective measurement model, it was clear that all the criteria for validity and reliability testing were fulfilled. This further provides proof and support towards the validity and reliability testing of the reflective measurement model.

\subsection{CONCLUSION}

As a conclusion of the analyses, a Green Skills model has been developed. This model consisted of 10 elements of Green Skills which are environmental awareness, green practices, learning skill, career development skill, STEM skill, entrepreneur skill, communication skill, interpersonal skill, self-management skill, intellect skill, attitude, knowledge and values. The researchers hope that this instrument can be used by the related parties in producing high-skilled work force. Thus, this research findings can contribute and be used as a guidance by the Technical and Vocational Education Curriculum Development Department and other stakeholders in producing individuals who possess green skills and able to care for the environment. TVET should play a crucial role in spreading the sustainability elements among future generations. The elements of sustainability including green skills have long been incorporated in the curriculum, but no positive effects from implementation aspect. Therefore, TVET should play its role in introducing green skills in the process and teaching and learning in order to provide better exposure regarding the importance of sustainability in producing work force that are not only skilled, but also aware of the environment. Curriculum sustainability is utmost important in in overcoming challenges in the rapid growth of the country, knowledge regarding green skills can also be used to create and innovate new designs in the industry, apart from solving environmental problems such as global warming that requires immediate solution. Thus, for sustainability skills, integration of green skills is the right term to preserve TVET. All the elements of green skills need to be cultivated among the students which include attitude, knowledge and values in order to produce students who are sensitive toward the environment and become skilled human capital in all aspects of life.

\section{Acknowledgement}

The author would like to express her deepest gratitude to the Ministry of Higher Education of Malaysia for providing the financial assistance to complete this research under the project FRGS (Fundamental Research Grant Scheme), 2015-0166-107-02 (FRGS/1/2015/SS109/UPSI/03/13) year 2015-2018. The authors also wish to express her appreciation for the constructive comments she received from anonymous reviewers.

\section{References}

Arasinah, K., Amarumi, A., Bushra Limuna, I., Normah, Z., \& Faizal Amin, N. Y. (2017a). Integration of Green Skills in Sustainable Development in Technical and Vocational Education. International Journal of Engineering Research and Applications (IJERA), 7(12), 08-12. ISSN: 2248-9622. www.iiera.com.

Arasinah, K, Ridzwan, C. R, Mohd Bekri, R, Faizal, A, N. Y, Normah, Z., \& Haryanti, M. A. (2017b). Exploring Green Skills: A Study on the Implementation of Green Skills among Secondary School Students, International Journal of Academic Research in Business and Social Sciences, 7(12), $327-34$.

Arasinah, K., Mustapha, R., Waliza, A. B., \& Bushra Limuna, I. (2016). Green Skills as an added-value element in producing competent students. International Journal of Engineering Research and Applications, 6(11), 12-21.

Bushro Limuna, I, Arasinah, K., Che Ghani, C. K., Kiong, T. Z., \& Md. Bekri, R. (2016). Integrating element of green skills in the $21^{\text {st }}$ century learning in ICEDU $3^{\text {rd }}$ International Conference on Education, 20-22 April, 2016, Kuala Lumpur, Malaysia. http://ecuationconference.co/presentations/

Babbie, E. (2001). The Practice of Social Research, (9th. Ed.). Belmont, CA: Wadsworth Publication Company.

Bartlett, J. E, Kotrlik, J. W \& Hinggins, C. C. (2001). Organizational Research: Determining Appropriate Sample Sizein Survey Research. Information Technology, LearninG and Performance Journal, 19(1), 43-50.

Bentler, P. M. (1990). Comparative fit indexes in structural models. Psychological Bulletin, 107, 238-246.

Bentler, P. M., \& Bonnet, D. G. (1980). Significance Tests And Goodness-Of-Fit In The Analysis Of Covariance Structures. Psychological Bulletin, 88, 588-606.

Byrne, B. M. (2010). Structural Equation Modeling With AMOS: Basic Concepts, Applications, And Programming (2 ${ }^{\text {nd }}$ ed.). New York, London: Taylor and Francis Group.

CEDEFOP (European Centre for the Development of Vocational Training). (2012a). A Strategy For Green Skills? A Study on Skill Needs and Training has Wider Lessons for Successful Transition to a Green Economy: Briefing Report. Greece: European Centre for the Development of Vocational Training.

CEDEFOP (European Centre for the Development of Vocational Training). (2010a). Skills for Green Job: European Synthesis Report. Luxembourg: Publication Office.

Cochran, W.G. (1977). Sampling Technique. New York: John Willey and Sons.

Creswell, J. W. (2013). Research Design: Qualitative, Quantitative, and Mixed Methods Approaches. SAGE Pulications.

Diep, P. C. \& Hartmann, M. (2016). Green Skills in Vocational Teacher Education - a model of pedagogical competence for a world of sustainable development. In: TVET@Asia, issue 6, 1-19. Online: retrieved from http://www.tvet-online.asia/issue6/diep_hartmann_tvet6.pdf .

Erdogan, M. (2015). The Effect of Summer Environmental Education Program (SEEP) on Elementary School Students' Environmental Literacy. International Journal of Environmental \& Science Education, 10(2), 165-181.

Ernesto L. D. L. (2004). Awareness, Knowledge \& Attitude about Environmental Education: Response from Environmental Specialist, High School Instructors, Students and Parents. Orlando: University of Central Florida.

Fornell, C., Larcker, D. F. (1981). Evaluating Structural Equation Models With Unobservable Variables And Measurement Error. Journal of Marketing Research, 18 (1), 39-50.

Frank, C. Leeming, William O'Dwyer, \& Bruce, A, Bracken. (1995). Children's Environmental Attitude and Knowledge Scale. Retrieved 14/5/2013 from http://www.meea.org/melab/CHEAKS.pdf .

Giolitte. P, Mathot. L, Pardo. A, \& Vergnes, G. (1997). Environmental Education in the European Union. Brussels,Luxembourg. 
Habsah, I.. (2000). Kefahaman guru terhadap konsep pendidikan bersepadu dalam KBSM. In Malay. Bangi: Universiti Kebangsaan Malaysia.

Hair, J. F., Black, B., Babin, B., Anderson, R. E., \& Tatham, R. L. (2010). Multivariate Data Analysis: A Global Perspective (7 ${ }^{\text {th }}$ ed.). New Jersey, USA: Pearson Education Inc.

Hanifah, M. (2014). Kesedaran dan Komitmen Pendiidkan Pembanguna Lestari Dalam Komuniti Sekolah Menerusi Program Sekolah Lestari di Malaysia. In Malay: Thesis: Universiti Pendidikan Sultan Idris.

Hasnah, A., Dody, D., Noraziah, A., Maznah, I., \& Sarifah, Y.. (2012). Masyarakat dan Amalan Pengurusan Sisa Pepejal ke arah Kelestarian Komuniti: $\quad$ Kes $\quad$ isi rumah wanita di Bandar Baru Bangi, Malaysia. In Malay: Geografia Malaysia Journal of Society and Space, 29(5), $426-436$.

Hatcher, L. (1994). A Step-By-Step Approach To Using SAS For Factor Analysis And Structural Equation Modeling. Cary, NC: SAS Institute Inc.

Hu, L., \& Bentler, P. M. (1999). Cutoff Criteria For Fit Indexes In Covariance Structure Analysis: Conventional Criteria Versus New Alternatives. Structural Equation Modeling, 6, 1-55.

Hungerford, H. R., Bluhm, W.J., Volk, T. L., \& Ramsey, J. M. (1998). Essential Readings In Environmental Education. Stipes Publishing, Champaign, Illinois.

Jamilah, A. \& Hasrina, M. (2011). Pengetahuan, Sikap, Dan Amalan Masyarakat Malaysia Terhadap Isu Alam Sekitar. Bangi, Selangor: Universiti Kebangsaan Malaysia.

Licy, C., Vivek, R., Saritha, K., Anies, T., \& Josphina, C. (2013). Awareness, Attitude and Practise of Scholl Students toward Household Waste Management. Journal of Environment, 147-150.

McDonald, G., Condon, L., \& Riordan, M. (2012). The Australian Green Skills Agreement Policy And Industry Context, Institutional Response And Green Skills Delivery. Broadway, Australia: TAFE Directors Australia.

Meenakshi, S. \& Leela, R. (2014). Environmentally Sustainable Consumption: A Review And Agenda For Future Research. Global Journal of Finance and Management. 6(4), 367-374

Marsh, H. W, \& Hocevar, D. (1985). Application of Confirmatory Factor Analysis to the Study of Self-Concept: First and Higher-Order Factor Models and Their Invariance Across Groups. Psychological Bulletin, 97(3), 562-582.

Mac Diarmid, J. I., Douglas, F., \& Campbell, J. (2016). Eating Like There's No Tomorrow: Public Awareness Of The Environmental Impact Of Food And Reluctance To Eat Less Meat As Part Of A Sustainable Diet. Appetite, 96, 487-493.

Mead, N. (2003). Will the Introduction of Teaching Standards in Professional Values and Practice Put the Heart Back into Primary Teacher Education? An International Journal of Personal, Social and Emotional Development, 21, 37-42.

Mohd Ali, S., Abdul Hadi, H., Norfarah, N., Noor Hasyimah, H., \& Corrienna, A. T... (2014). The Effect off Online Project-Based Learning on Students Attitudes towards Renewable Energy. Malaysian Journal of Distance Education, 16(2), 39-57.

Mukesh Kumar Panth, Preetam Verma \& Mansi Gupta. (2015). Environmetal Awareness, Role of Attitude. LAP Lambert Academic Publishing.

Mustafa, M.. (2010). A Study On Developing A General Attitude Scale About Environmental Issues For Students In Different Grade Levels. Asia-Pacific Forum on Science Learning and Teaching, 11(2), Article 3,

Narendra Singh, \& Karnika Gupta. (2013). Assessment of Emotional Intelligence Across Demographic Variables. Journal of Indian Health Psychology, 8(1), 21-41.

Nor Kalsum, M. I.. (2016). Pengetahuan, Sikap dan Tingkah Laku Pelajar UPSI Terhadap Prinsip-Prinsip Kampus Lestari. Jurnal Perspektif, 8(1), 29-41.

Othman, M. N., Ong, F. S. and Lim, M. H. 2004. Environmental Attitudes And Knowledge Of Teenage Consumers. Malaysian Journal of Consumer and Family Economics, 7, 66-78.

Pavlova, M. (2012). Generic Green Skills: Can They Be Addressed Through Technology Education?. Griffith University.

Pavlova, M. \& Huang, C. L. (2013). Advancing Employability And Green Skills Development: Values Education In TVET, The Case Of The People's Republic Of China, In Skills Development For Inclusive And Sustainable Growth In Developing Asia-Pacific. Technical and Vocational Education and Training. Issues, Concerns and Prospects, 18, 327-343.

Palmer, J., \& Neal, P. (1998). The Handbook of Environmental Education. London: Routledge.

Ramlee, M.. (2015). Green and Sustainable Development for TVET in Asia. The International Journal of Technical and Vocational Education, 11(2), 133-142.

Ramsey, C. E., \& Rickson, R. E. (1976). Environmental Knowledge And Attitudes. Journal of Environmental Education, 8(11), 10-18.

Rohana, S., Norazlina, S. \& Khairuninsa, R.. (2013). Managing Public Transport Service Operation In Reducing Travel Fear Factor. Procedia-Social and Behavioral Sciences, 101, 338-344.

Rose Aminah, A. R. (2015). Improving Attitude towards Green Environment Awareness Through the SLGEA-code module. International Journal of Technical Research and Applications, 5(3), 26-31.

Saravanan, Rosta H. \& Ahmad, M. (2013). Amalan Penggunaan Lestari Dalam Kalangan Pelajar Tingkatan Empat Di Daerah Kluang Johor. Persidangan Kebangsaan Geografi Dan Alam Sekitar Kali Ke-4, 169-180. Jabatan Geografi dan Alam Sekitar, Fakulti Sains Kemanusiaan, Universiti Pendidikan Sultan Idris, Tanjung Malim on 5-6 Mac.

Shahrom, M. Z., Noor Ezlin, A. B., Fatihah, S., Othman, J., \& Hassan, B. (2015). Pendidikan Alam Sekitar: Bagaimana Usaha-Usaha Dilakukan Dalam Proses Pengajaran Dan Pembelajaran. Bangi Selangor : UKM.

Siti Nor Syazwani, S., Mohd Safarin, N. \& Muhammad Sukri, S. (2012). Integrasi Teknologi Hijau Dalam Kurikulum Pendidikan Teknik dan Vokasional (PTV). In Malay: Journal of Technical, Vocational \& Engineering Education, 5, 11 - 19.

Strietska-Ilina, O., Hofman, C., Duran Haro, M., \& Jeon, S. (2011). Skills for Green Jobs: A Global View. Synthesis Report Based on 21 Country Studies. Executive Summary. Geneva: International Labour Organisation.

Stuhmcke, M. S. (2012). Children as Change Agents For Sustainability, An Action Research Case Study In A Kinder Garden. Faculty of Education. Queensland University of Technology.

Suhaimi. N., Mahmud, S. M. Z., Mohamad Ariff, N. A., Hamzah, R., \& Saud, M. S. (2010). Pelestarian Kurikulum Pendidikan Teknik Dan Vokasional. https://www.scribd.com/doc/74807856/Eprint16-Pelestarian-Kurikulum-Pendidikan-Teknik-Dan-Vokasional. [accessed 26th July 2017].

Schumacker, R., \& Lomax, R. G. (2010). A Beginner's Guide to Structural Equation Modeling (3 ${ }^{\text {rd }}$ ed.). New York: Routledge, Taylor \& Francis Group.

Sterling, S., \& Cooper, G. (1992). In Touch: Environment Education for Europe. Surrey, UK: WWF, Panda House.

Tabachnick, B. G., \& Fidell, L. S. (2013). Using Multivariate Statistics (6 ${ }^{\text {th }}$ ed.). Boston, MA: Pearson Education Inc.

Taylor, N. Quinn, F. \& Eames,C. (2015). Educating for Sustainability in Primary Schools Teaching for the Future. Sense Publishers.

Teoh, E. S. (2016). An Evaluatian of Enviromental Education In Selected Primary Schools In Pahang, Malaysia. PhD Thesis Disertation. UPSI.

Tiwi Kamidin, \& Roslan, S. (2014). Pendekatan Ekopsikologi dalam Pelaksanaan Pendidikan Alam Sekitar. Penerbit Universiti Putra Malaysia.

UNEVOC, International Centre for Technical and Vocational Education and Training. (2012). http://www.unevoc.unesco.org/. [Accessed 3th May 2016]. 